O. Butenko, PhD, Assoc. Prof.,

K. Vasiutynska, PhD, Assoc. Prof.,

S. Smyk, PhD, Assoc. Prof.

Odessa National Polytechnic University, 1 Shevchenko Ave., Odessa, Ukraine, 65044; e-mail: alex_butenko@ukr.net

\title{
DEVELOPMENT OF DOUBLE-CIRCUIT CLOSED-LOOP DEDUSTING SYSTEM FOR INCREASING THE ATMOSPHERE SAFETY LEVEL
}

\begin{abstract}
О.Г. Бутенко К.А. Васютинська, С.Ю. Смик. Розроблення двухконтурної замкнутої системи знепилювання для підвищення рівня екологічної безпеки атмосферного повітря. Технологічні процеси численних виробництв є джерелами викидів полідисперсного пилу у виробничі приміщення та навколишній повітряний простір. Директива 2008/50/€С встановлює досить жорсткі вимоги до вмісту твердих часток ТЧ 10 и ТЧ2,5, а саме такі фракції складають основну частину маси проскоку традиційних пиловловлювачів. Тож, підвищення ефективності видалення дрібнодисперсних фракцій системами знепилювання аспіраційного повітря є сучасним і актуальним завданням. Метою статті є підвищення рівня екологічної безпеки атмосферного повітря в районах близького розміщення промислових виробництв і житлової забудови шляхом модернізації системи очищення аспіраційного повітря. В статті пропонується заміна традиційної прямоточної системи на двухконтурну замкнуту. Екологічний ефект досягається за рахунок роздільної очистки пилових мас з різним фракційним складом і повної ізоляції системи від навколишнього середовища. Застосування розробленої методики розрахунку іiі показників дозволило оцінити величини експлуатаційних показників конкретної системи, зокрема, ефективності уловлення основного і циркуляційного апаратів, фракційний склад пилової маси на різних ділянках системи. Ефективність основного уловлювача становить $92 \%$. Методика оцінювання показників застосована для розрахунку аспіраційної системи очищення повітря з робочих приміщень подрібнення будматеріалів. Методом ситового аналізу побудована диференційна крива розподілу пилу, що входить в систему очищення. Методика дозволила побудувати криві розподілу фракційного складу для всіх потоків системи, а також динаміку ефективності основних і циркуляційного уловлювачів за розглянутий період роботи. Запропоновані геометричні параметри сухих інерційних уловлювачів для основного та циркуляційного контурів. Зроблені висновки, що надзвичайно висока ефективність сухого інерційного апарату, на відміну від традиційних прямоточних пиловловлювачів, досягається за рахунок керування фракційним складом пилової маси, що рухається по системі очищення.

Ключові слова: екологічна безпека, система очищення аспіраційного повітря, фракційний склад пилу, диференціальна крива розподілення, коефіцієнт уловлювання
\end{abstract}

O. Butenko, K. Vasiutynska, S. Smyk. Development of double-circuit closed-loop dedusting system for increasing the atmosphere safety level. Technological processes of numerous industries are sources of polydisperse dust emissions into the working areas and the environmental air. Directive 2008/50/EC establishes strong enough requirements for the content of PM10 and PM2.5 solids, but namely such fractions constitute the main of the dust slippage of traditional dust collectors. Therefore, efficiency increase of fine particles removal in the dedusting aspiration systems is an extremely valuable and timely task. The purpose of this article is to increase the level of environmental safety of atmospheric air in areas of close placement of industrial and residential areas by the modernization of the aspiration system. The article proposes the replacement of a traditional direct-flow system with a dual-circuit closed-loop. The ecological effect is achieved due to separate cleaning of dust with different grain-size distribution and complete isolation of the system from the environment. Applying the developed method of calculating it is possible to estimate the values of exploitable parameters for certain system, particularly, capture efficiency of dust in the main and recirculation devices, the grain-size distribution of the dust on different units of system. The effectiveness of the main catcher is $92 \%$. Method of parameters assessment was used to calculate the aspiration system for cleaning air from the working rooms of crushing building materials. Differential distribution curve based on the dispersed analysis was drawn for dust entering the cleaning system. Method had allowed us to draw distribution curves of the grain-size dispersed composition for all flows of the system, as well as the dynamics of efficiency of the main devices and circulation catcher during the described period of work. The geometrical parameters of dry inertial devices for the main and circulation circuits are proposed. It is concluded that the extremely high efficiency of the dry inertial device, unlike traditional dry dust collectors, is achieved by controlling the dispersed composition of the dust moving along the cleaning system.

Keywords: environmental safety, aspiration cleaning system, dispersed composition of dust, differential distribution curve, catching factor

\section{DOI: 10.15276/opu.3.56.2018.11}

(c) 2018 The Authors. This is an open access article under the CC BY license (http://creativecommons.org/licenses/by/4.0/). 
Introduction. Active urban fringe development leads to placement of residential areas near the existing industrial enterprises. It is possible to give functioning of powerful cement plant within the Suvorov district of Odessa as an example. On the one hand, approach of production of construction materials to the site is economically proved. But environmental impacts which relate to emissions of cement dust lead to escalation of the environmental hazard of urban atmospheric air.

According to the requirements of Directive 2008/50/EC [1], in order to prevent harmful industrial dust impacts on human health and the environment, it is necessary to set pollution limits for particulate matter $\mathrm{PM}_{10}$ and $\mathrm{PM}_{2.5}$. In compliance with the pan-European standards, highly dispersed particles constitute the most dangerous part of dust-gas-aerosol emissions. Such fractions remain in dust emissions after mechanical treatment.

Technological processes of many industries placed in the city, accompanied by the large amounts of polydisperse dust exhausting into the air of industrial premises, and then into the environment. Sometimes the physical or chemical parameters of the dust mass are such that it is necessary to limit their exhausting to the environment as much as possible; sometimes the dust mass is a useful substance (for example, cement dust) and it is not economically feasible to divert it into the environment. Existing dedusting system of aspiration air, as a rule, are direct-flow and therefore part of the dust slippage dissipated into the environment. The relative part of dust emissions depends on the capture efficiency of devices used, but a common drawback of these systems is the inability to eliminate leakage.

Major energy, chemical and metallurgical plants are currently investing heavily in environmental protection actions, including ash and dust separation. The situation is different for small enterprises located mainly in or near settlements. These enterprises are not able to invest in high-performance equipment and are still often used dry inertial separators. The efficiency of their work does not accord to today environmental safety requirements.

Analysis of recent research and publications. The main problem of most common dust precipitators, especially inertia, is the low efficiency of separation of fine dust particles. Therefore, most of the current research in this area is focused on improving this aspect of equipment [2]. However, the ways to increase the efficiency of separating fines fractions by changing the design of common precipitators are almost exhausted.

Therefore, most of the research is aimed to solving this problem by acting on the dispersed composition of dust. For example, in articles [3 - 5] an acoustic coagulation method is proposed. In articles $[6,7]$ a combined cleansing system (CCS) was offered. According this, polydisperse dust is first divided in a separating apparatus into fractions. Then the stream with coarse dust enters the main precipitator, and the stream with fine particles is purified by repeated passage of the capture of the circulation circuit. Since the efficiency of coarse-dust capturing is high (even in dry inertial devices), the leakage to the environment is minimal. This ensures the ecological effect.

The purpose of this article is to increase the level of environmental safety of atmospheric air in areas of close placement of industrial and residential areas by the modernization of the aspiration system.

Within the framework of this goal, the tasks of theoretical analysis of the effectiveness of CCS and evaluation of application experience were solved. The application of such dust cleaning device did not require significant capital investments but provided a significant improvement in dedusting thanks to a separate cleaning scheme.

However, despite its effectiveness, CCS itself does not completely isolate the environment from pollution. Therefore, to solve this problem, in this article to modernize CCS so that it retains its main advantage - separate cleaning of large and small particles and isolates the dust flow from the environment is propose.

\section{Presentation of the main material.}

The schematic diagram of the double-circuit closed-loop cleaning system (DCCLS) is presented in Fig. 1. According to the scheme, the primary air flow with the dust mass ( $M_{1-2}$ per second), which captured by the collection-return unit (CR) (1), does not flow directly into the capture. It mixed with pre-cleaned flow of the circulation circuit in central ejector (2), and then enters to the separator (3) in which is separating into two parts in compliance with fractional composition. Flow with fine dust par- 


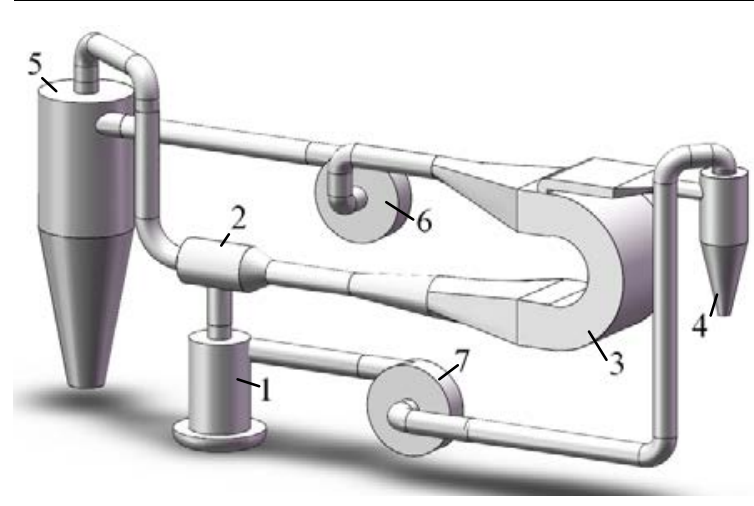

Fig. 1. Scheme of the double-circuit closed-loop cleaning system: 1 - collecting - return unit;

2 - mixing device; 3 - separating device; 4 - main circuit capture; 5 - capture of the circulation circuit; 6 - circulation fan; 7 - main circuit fan

ticles $M_{3-5}$ mass directed to the catcher of circulation circuit (5), and the flow with large dust particles $M_{3-4}$ mass - to the main capture (4). Since the capture efficiency of large particles is high, the dust slippage $\left(M_{4-1}\right)$ in the device is insignificant. This dust is returned into the CR work zone and again after capture falls on cleaning. The flow of the circulation $M_{5-2}$ mass after cleaning is mixed in the ejector (2) with the primary flow and again through the separator directed to cleaning.

Thus, firstly, the removal of fine particles is ensured due to repeated passage of dusty flow through the capture, and, secondly, the system is loop-closed, so air pollution is excluded.

The system can be configured with various standard injections and cleaning equipment depending on physical properties and the dispersed dust composition. A central ejector is used as a mixing device. The separating device is constructed according to the results of [8].

The collecting and returning stage are proposed to be designed using the scheme in which the dust and gas flow is collected through a cylindrical pipe, and the cleaned gas is returned to the work room through an annular coaxial channel (Fig. 2). The inlet of supply gas flow is tangentially connected to the device. This design provides a twist flow and high compactness of a free jet at the unit CR. This, in turn, improves the secondary capture of dust leakage in the main catcher.

The CR includes volumetric flow rate of aspiration air $Q_{1-2}$, which contains a dust from the sources of emissions $M_{0}$ and the dust leakage of the main catcher $M_{4-1}$.

$$
M_{1-2}=M_{0}+M_{4-1}=Q_{1-2} C_{0}+M_{4-1},
$$

where $M_{4-1}-$ mass per second of returning dust, $\mathrm{kg} / \mathrm{s}$;

$C_{0}$ - concentration of dust in primary stream, $\mathrm{kg} / \mathrm{m}^{3}$.

The Differential Curve of Distribution (DCD) of the weight taken thus (as a percentage):

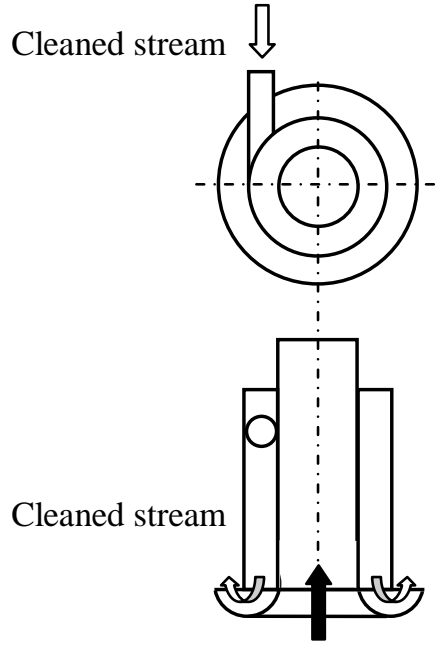

Dusty stream

Fig. 2. The design of unit "collecting - return"

$$
N_{1-2}=\frac{\left(M_{0}^{i}+M_{4-1}^{i}\right) 100}{\left(M_{0}+M_{4-1}\right) 10},
$$

where $M_{0}^{i}$ - mass per second of $i$-th particles of dust leakage;

$M_{4-1}^{i}$ - mass per second of $i$-th dust particles, from the source of dusting (dust mass of the entire range of particle sizes is divided into 10 equal segments).

The mass enters the mixing device:

$$
M_{2-3}=M_{1-2}+M_{5-2} \text {. }
$$

DCD of which:

$$
N_{2-3}^{i}=\frac{\left(M_{1-2}^{i}+M_{5-2}^{i}\right) 100}{\left(M_{1-2}+M_{5-2}\right) 10} .
$$

Mass per second of dust slippage in the catcher of the circulation circuit, $\mathrm{kg} / \mathrm{s}$ :

$$
M_{5-2}=M_{3-5}\left(1-\eta_{c}\right),
$$

where $\eta_{c}$ - capture coefficient of the circulation circuit device.

DCD of this mass: 


$$
N_{5-2}^{i}=\frac{M_{3-5}^{i}\left(1-\eta_{c}^{i}\right) 100}{M_{3-5}\left(1-\eta_{c}\right) 10},
$$

where $\eta_{c}^{i}$ - partial capture coefficient of the circulation circuit device.

The volumetric flow rate of air entering the separator:

$$
Q_{2-3}=Q_{1-2}+Q_{5-2} \text {. }
$$

Mass is supplied into the main catcher:

$$
M_{3-4}=M_{2-3} \eta_{s}
$$

where $\eta_{s}$ - the part of dust, which falling from the separator into the main catcher (separation ratio) [6].

DCD of which:

$$
N_{3-4}^{i}=\frac{M_{2-3}^{i} \eta_{s}^{i} 100}{M_{2-3} \eta_{s} 10} .
$$

Mass is supplied into the circulation circuit catcher:

DCD of which:

$$
M_{3-5}=M_{2-3}\left(1-\eta_{s}\right) \text {. }
$$

The volumetric flow rate of air:

$$
N_{3-5}^{i}=\frac{M_{2-3}^{i}\left(1-\eta_{s}^{i}\right) 100}{M_{2-3}\left(1-\eta_{s}\right) 10} .
$$

$$
Q_{3-4}=Q_{2-3} q_{m}, Q_{3-5}=Q_{2-3}\left(1-q_{m}\right) \text {, }
$$

where $q_{m}$ - the part of volumetric flow rate from the separator to the main catcher [8].

Capture coefficient of the main device:

$$
\eta_{m}=\sum_{i=1}^{10} \frac{\eta_{m}^{i} N_{3-4}^{i} 10}{100},
$$

where $\eta_{m}^{i}$ - partial capture coefficient of the main device.

Capture coefficient of the circulation circuit device:

$$
\eta_{c}=\sum_{i=1}^{10} \frac{\eta_{c}^{i} N_{3-5}^{i} 10}{100}
$$

where $\eta_{c}^{i}$ - partial capture coefficient of the circulation circuit device.

Mass, which captured in the main device:

$$
M_{4}=M_{3-4} \eta_{m} .
$$

Mass, which captured in the circulation circuit device:

$$
M_{5}=M_{3-5} \eta_{c} .
$$

Mass of dust slippage of the main catcher:

$$
M_{4-1}=M_{3-4}\left(1-\eta_{c}\right) \text {. }
$$

The evaluation method of indicators was applied to calculate the system developed for cleaning the aspiration air at the processes of building materials crushing. Dispersed analysis of samples collected dust allowed us to obtain a differential distribution curve (DDC) $N_{m}^{i}=f(\Delta)$ (curve 1 in Fig. 4). Dust density determined pycnometric method, was $2046 \mathrm{~kg} / \mathrm{m}^{3}$. The relative slit thickness of selection of the base flow in separator taken equal to $\bar{a}=0.1$. In this case, $4.77 \%$ of gas flow rate enters to the main channel, and $95.23 \%$ - to the circulation circuit.

The volume flow of dusty air at the entrance to the system should be equal to that of the main channel $Q_{1-2}=Q_{4-1}$. It was equal $3.810^{-2} \mathrm{~m}^{3} / \mathrm{s}$. This condition corresponds to the flow rate of the circulation circuit $Q_{3-5}=0.762 \mathrm{~m}^{3} / \mathrm{s}$ and the flow rate at the outlet of the ejector to the separating device $Q_{2-3}=0.8 \mathrm{~m}^{3} / \mathrm{s}$. Cyclones (which to be manufactured) geometric parameters were calculated from these data, and as a prototype battery element had taken BCU cyclone type "Energougol". 
The dependencies for the partial coefficients of cyclone capture were calculated also $\eta_{m}^{i}=f(\Delta)$ and $\eta_{c}^{i}=f(\Delta)$, which needed to evaluate the effectiveness of the system.

Since the customer's technical task did not indicate the mass per second of dust emitted by the crusher, $M_{0}$ conditionally accepted taken equal to one and the calculations were carried out in proportion of this value.

A specific feature of DCCLS is that after the dust emission finished (stopping of the crushing plant), a short period of work is required to capture the dust of the circulation circuit - the run-out time. Therefore, the calculation of the system was carried out for system standard (regular) mode and mode run-out $\left(M_{0}=0\right)$.

Fig. 3 shows the curves of efficiency changes of different units of DCCL. Here, the first 35 cycles are the time of the standard cleaning mode, the next 25 are the run-out time (the cycle time is the time during which the flow makes a complete turn along the circulation circuit).

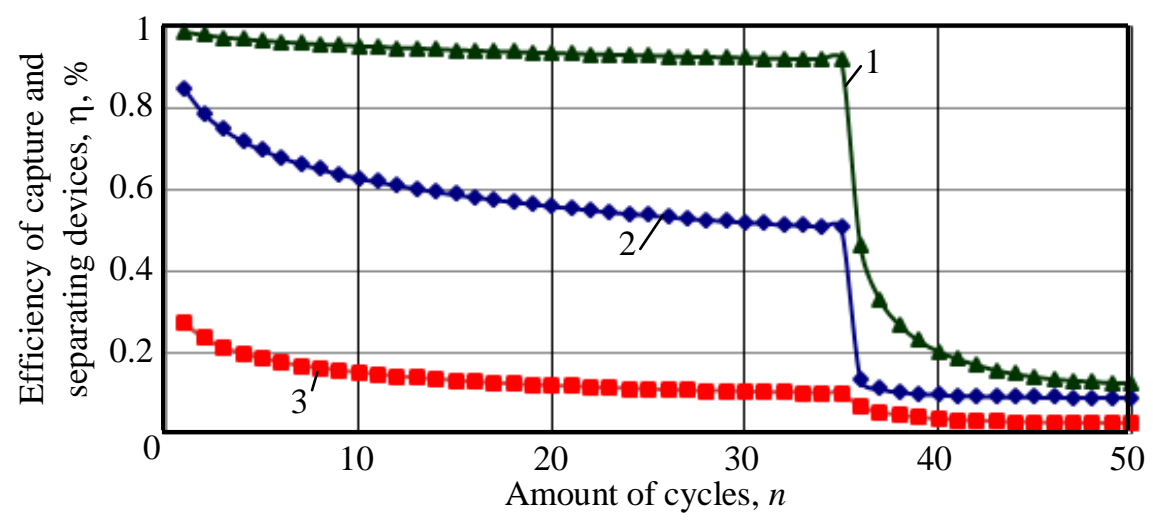

Fig. 3. Dynamics of changes of $\eta_{m}(1), \eta_{s}(2)$ and $\eta_{c}(3)$ during the operation of the cleaning system

The differential distribution curves (DDC) of all dusty gas flows were calculated also. The distribution curves for $M_{2-3}$ и $M_{3-5}$ given as an example шn Fig. 4 and 5.

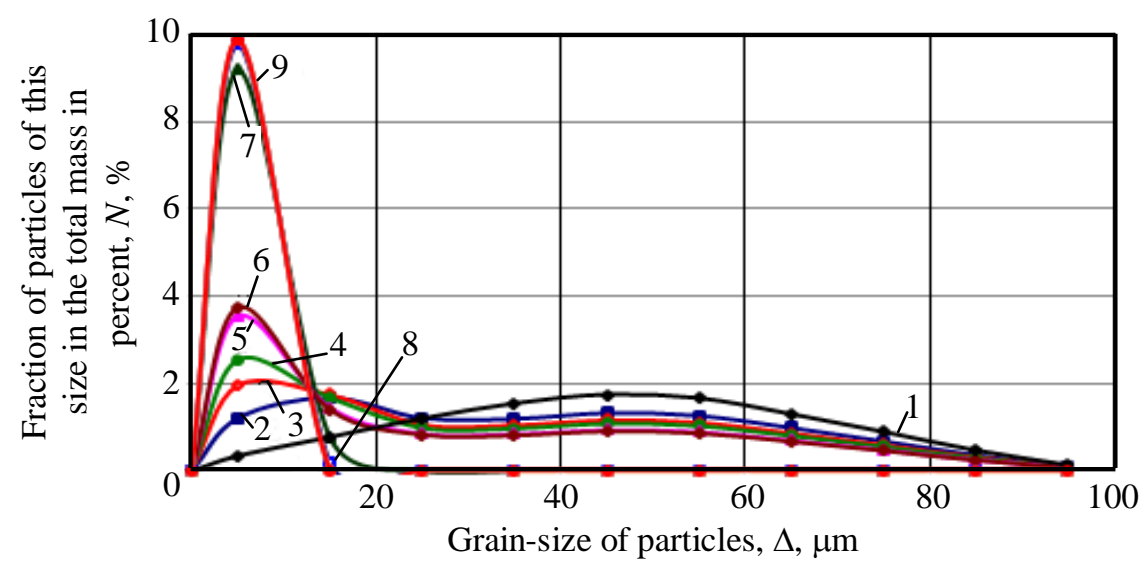

Fig. 4. Dynamics of DDC changes of dust mass $M_{2-3}$, standard mode: $1-n=1,2-n=5,3-n=10,4-n=15$, $5-n=30,6-n=35$; mode run-out: $7-n=40,8-n=45,9-n=60$ 


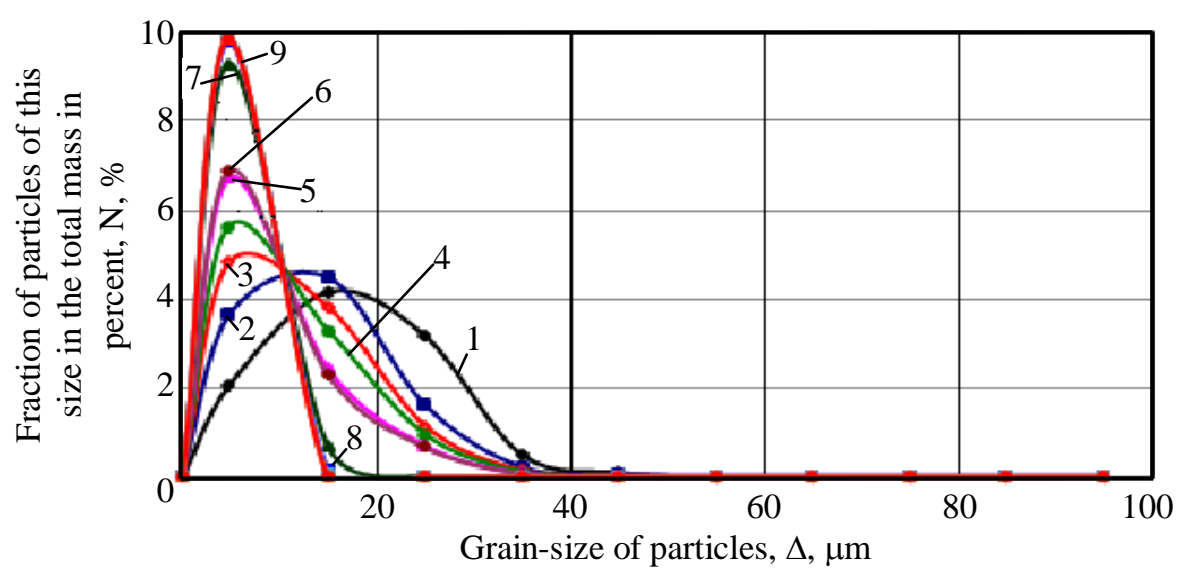

Fig. 5. Dynamics of DDC changes of dust mass $M_{3-5}$, standard mode: $1-n=1,2-n=5,3-n=10,4-n=15$, $5-n=30,6-n=35$; mode run-out: $7-n=40,8-n=45,9-n=60$

Fig. 3 demonstrates that, either in the standard operation mode or in the coasting mode, both characteristic periods can be distinguished: the period of the variables and the period of their almost constant values. As can be seen from Fig. 4 and 5, this is explained by the fact that at the beginning of both modes the fractional composition of the dust mass changes significantly, and with time this change becomes insignificant.

The main DCCL integral indicator is the relative mass of dust, which for the entire period of work emissioned from the main circuit device to the workroom $M_{4-1}^{\Sigma} / M_{0}=2.902$ (1.911 falls on 35 cycles of standard mode and 0.991 per 25 run-out cycles). Therefore, the value $M_{4-1}^{\Sigma} / M_{0}$ can be reduced to 1.911, if to block access of dusty air into the main channel. A relative disadvantage of such operation is it will lead to a slight increase in run-out time.

\section{Conclusions.}

The research allowed offering environmentally safety system for cleaning aspiration air from polydisperse dust.

The system provides a separate cleaning principle and is loop-closed. The developed method of calculating the system parameters allows to determine the mass of dust per second and its DDC for all elements of the system in the mode of cleaning and running out.

Calculations by this method showed that the effectiveness of the main capture is $92 \%$. This value is untypically high for dry inertia catchers. It is achieved by controlling the dispersed composition of the dust mass. Thus, the system can significantly increase the level of environmental air safety in the areas of co-location of industrial and residential areas.

\section{Література}

1. Desert dust contribution to PM10 loads in Italy: Methods and recommendations addressing the relevant European Commission Guidelines in support to the Air Quality Directive 2008/50. / Barnaba F., Bolignano A., Di Liberto L., Morelli M., Lucarelli, F. Nava S., Gobbi G. P. Atmospheric Environment. 2017. Vol. 161. P. 288-305. DOI: 10.1016/j.atmosenv.2017.04.038.

2. Koshkarev S., Evtushenko A., Pushenko S. Evaluation of Solid Particles Slippage’ Amount Throw out wet Dust Cleaning Device in the Dust Removal System in Building Industry. Procedia Engineering. 2016. Vol. 165. P. 1057-1069. DOI: 10.1016/j.proeng.2016.11.820.

3. Experimental study on improving the efficiency of dust removers by using acoustic agglomeration as pretreatment. / Zhou D., Luo Z., Jiang J., et al. Powder Technology. 2016. Vol. 289. P. 52-59.

4. Ngu F, Xiong J, Wan M. Application of acoustic agglomeration to enhance air filtration efficiency in air-conditioning and mechanical ventilation (ACMV) systems. US National Library of Medicine. National Institut of Health. 2017. Vol. 12(6). DOI: 10.1371/journal.pone.0178851. 
5. Preliminary Experimental Study of Acoustic Agglomeration of Coal-fired Fine Particles. / Zhou D, Luo Z, Fang M., et al. Procedia Engineering. 2015. Vol. 102. P. 1261-1270.

6. Karamushko A.V. Cleaning the gas flow from polydisperse dust in the apparatus of dynamic action. The international journal of Sustainable development. 2018. Vol. 8, № 1. P. 68-73. URL: https://docs.wixstatic.com/ugd/2f29d0_0ff83b85a749447db7bc0b42849317c0.pdf.

7. Бутенко О.Г., Смик С.Ю. Гідравлічний розрахунок комбінованої системи очищення повітря. Праці Одеського політехнічного університету. 2011. Вип. 1(35). С. 191-195.

8. Бутенко А.Г., Смык С.Ю., Мовила Д.А. Разделение твердой фазы полидисперсного потока по фракциям в комбинированной системе очистки. Экология и промышиленность. 2009. Вып. 4. С. 68-70.

\section{References}

1. Barnaba, F., Bolignano, A., Di Liberto, L., Morelli, M., Lucarelli, F., Nava, S., \& Gobbi, G. P. (2017). Desert dust contribution to PM10 loads in Italy: Methods and recommendations addressing the relevant European Commission Guidelines in support to the Air Quality Directive 2008/50. Atmospheric Environment, 161, 288-305. DOI: 10.1016/j.atmosenv.2017.04.038.

2. Koshkarev, S., Evtushenko, A., \& Pushenko, S. (2016). Evaluation of Solid Particles Slippage’ Amount Throw out wet Dust Cleaning Device in the Dust Removal System in Building Industry. Procedia Engineering, 165, 1057-1069. DOI: 10.1016/j.proeng.2016.11.820.

3. Zhou, D., Luo, Z., \& Jiang, J., et al. (2016). Experimental study on improving the efficiency of dust removers by using acoustic agglomeration as pretreatment. Powder Technology, 289, 52-59.

4. Ngu, F, Xiong, J, \& Wan, M. (2017). Application of acoustic agglomeration to enhance air filtration efficiency in air-conditioning and mechanical ventilation (ACMV) systems. US National Library of Medicine. National Institut of Health, 12(6), http: DOI: 10.1371/journal.pone.0178851. Last accessed: 6 Dec 2018.

5. Zhou, D., Luo, Z., \& Fang, M., et al. (2015). Preliminary Experimental Study of Acoustic Agglomeration of Coal-fired Fine Particles. Procedia Engineering, 102, 1261-1270.

6. Karamushko, A.V. (2018). Cleaning the gas flow from polydisperse dust in the apparatus of dynamic action. The international journal of Sustainable development, 8, 1, 68-73. Retrieved from: https://docs.wixstatic.com/ugd/2f29d0_0ff83b85a749447db7bc0b42849317c0.pdf.

7. Butenko, O.G., \& Smyk, S.Yu. (2011). Hydraulic calculation of the combined air purification system. Proceedings of Odessa Polytechnic University, 1 (35), 191-195.

8. Butenko, A.G., Smyk, S.Yu., \& Movila, D.A. (2009). Separation of a solid phase of a polydisperse flow by fractions in a combined purification system. Ekologiya i promyshlennost', 4, 68-70.

Бутенко Олександр Григорович; Butenko Olexandr, ORCID: https://orcid.org/0000-0002-9814-4146 Васютинська Катерина Анатоліївна; Vasiutynska Kateryna, ORCID: https://orcid.org/0000-0001-9800-1033 Смик Сергій Юр'свич; Smyk Sergej, ORCID: https://orcid.org/0000-0001-7020-1826 